\title{
Growth Pattern of Social Media Usage in Arab Gulf States: An Analytical Study
}

\author{
Sulaiman Reyaee1, Aquil Ahmed ${ }^{2}$ \\ ${ }^{1}$ Department of Information Studies, Faculty of Computer and Information Sciences, Al-Imam Muhammed Ibn \\ Saud Islamic University, Riyadh, Saudi Arabia \\ ${ }^{2}$ Deanship of Library Affairs, Al-Jouf University, Sakaka, Saudi Arabia \\ Email: reyaee@ju.edu.sa, aahmed2006@gmail.com
}

Received 13 March 2015; accepted 2 April 2015; published 14 April 2015

Copyright (C) 2015 by authors and Scientific Research Publishing Inc.

This work is licensed under the Creative Commons Attribution International License (CC BY).

http://creativecommons.org/licenses/by/4.0/

(c) (i) Open Access

\begin{abstract}
The impact of SNSs is tremendous on every aspect of life and people irrespective of region, gender and age are using it to get connected with their families and friends around the globe. This study aims to highlight the highly used SNSs across the Arab Gulf States comprising Iraq, Kuwait, United Arab Emirates, Oman, Qatar, and Saudi Arabia. The database of Stat Counter (http://gs.statcounter.com) was selected for tracing the use and growth of SNSs in this region. The findings show that the three most used SNSs in the Arab Gulf region are: Facebook, Twitter and YouTube. It is observed that Facebook is the leading social networking site used in the region until now, but Twitter is fast gaining market. Twitter is becoming popular among users and giving a tough competition to Facebook in almost all countries of the region except Iraq. In 2013, it has moved to 1st position in Saudi Arabia and Kuwait, replacing Facebook. However, in some countries like the UAE and Qatar, Facebook is still going strong. The paper concludes that the intensive use of social media among citizens' of the Arab Gulf countries indicates that the internet has the potential to be a multivocal platform through which every segment of the society can have their voices heard. With limited availability of published literature in the field pertaining to the usage of social media by the people of the Arab Gulf countries, the paper aims to understand the practice, implication and importance of social media networks in this Muslim dominated region.
\end{abstract}

\section{Keywords}

Social Networks, Social Media, Facebook, Higher Education, Saudi Arabia

\section{Introduction}

The internet has revolutionized the economy and above all our society. It has become a natural, background part 
of everyday life. Today, the internet magnitude is thousand times more than what it was a decade ago. It is estimated that as of March 2014, about 40.7\% (2937 millions) of the world population are using the internet [1]. The evolutions of the social web and mobile technology have changed the way people use the internet. These two innovations coupled with powerful internet and networking technologies have created a global environment by drawing people of the world closer and closer together [2]. People started using internet applications like email, chatting, messaging, etc. to remain in touch with their friends and family around the globe. This extensive mesh of social interactions is termed as social networks, which gradually became a powerful tool for communication and managing social relations.

A social networking is an online service, platform, or a site that focuses on building and reflecting of social networks or social relations among people, who share interests or activities. Social networks encompass the interactions among different individuals, members of a community or members across different communities. Each individual in this social network is represented as node and the communications represent the links among these nodes [3]. Boyd and Ellison [4] defined social networking sites as "web-based services that allow individuals to 1) construct a public or semi-public profile within a bounded system, 2) articulate a list of other users with whom they share a connection, and 3) view and traverse their list of connections and those made by others within the system". According to White [5], SNSs can be defined as any web-based applications that allow people to connect, communicate, and collaborate with one another. This is generally done through constructing individual user profiles and allows users to share information and join networks based on geographic location or interests. In short, a social network service essentially consists of a description of each user, his/her social links, and a range of additional services. Most social network services are web based and provide a means for users to communicate over the internet, such as email and instant messaging.

Today SNSs have become a social and cultural phenomenon among a large number of internet users. According to the Global Digital Statistics 2014, 26\% of the world population are currently using social media. They are mainly used to connect people with each other in a variety of ways, including dating and meeting others with common interests and sharing information. They help to develop relationships that transcend age, race, social, culture, political and geographical barriers [6]. Arora [7] has rightly stated that the greatest impact of SNSs can be well understood by the ever-increasing number of people joining them all over the globe. There are hundreds of SNSs world over with various affordances, supporting a wide range of interests, activities and practices. The main purpose of these sites is to connect individuals, based on common language or shared racial, sexual, religious, national identities or shared interests, political views and activities. These sites also vary in their extent to which they incorporate new information and communication tools, such as mobile connectivity, blogging, and photo/video sharing, etc. [4]. The popularity of each social networking sites changes according to the features/services provided by that site in comparison with other sites. Furthermore, because of the fact that each social networking site has different features and functionalities, people tend to register with several social networks to satisfy different needs [8]. Table 1 lists the nature and growth of some of the popular Social Networking Sites.

\section{Social Media in the Arab Gulf States}

The literature search in this study indicates that new social networking sites are constantly popping up while the existing ones changing. The future of this area of the internet looks brighter. Though some argue that internet mediated communication is an "impoverished and sterile form of social exchange compared to traditional face to face interactions" [9]. Many studies have shown the opposite, that these sites actually improve communication between people [3] [4] [10] [11]. As Luo [12] rightly asserted that "the internet's social aspect remains a significant driver of content and connections today". Hempel [13] and Dwyer [14] found that people use social networking sites to maintain existing relationships and develop new ones. They claimed an increase in their social productivity and reported the use of social networking sites to re-establish connections with lost friends and families.

Extensive literature exits detailing the myriad ups and downs associated with social media across the globe [15]. As far as the Arab world is concerned, usage of social media has been extensive, yet there is very little current, comprehensive and accurate accounting of social media use is available [16]. According to the Arab Social Media Outlook 2014 [17], Social media is actively competing with conventional media as a primary source of news for millions of Arabs. Nearly 71 million Arabs reported using social media by the end of 2013 out of a total of 135 million individuals using the Internet. Studies have revealed that new technology has 
Table 1. Population and growth rate of social networking sites.

\begin{tabular}{|c|c|c|c|c|}
\hline SNS Name & Year Created & Created by & Active Users & Description/Focus Areas \\
\hline Facebook & 2004 & Mark Zuckerberg & $\begin{array}{l}\text { 1184 Million } \\
\text { (Jan. 2014) }\end{array}$ & General social networking site \\
\hline Twitter & 2006 & Jack Dorsey & $\begin{array}{l}232 \text { Million } \\
\text { (Jan. 2014) }\end{array}$ & $\begin{array}{l}\text { Mobile social networking site, } \\
\text { Micro-blogging }\end{array}$ \\
\hline YouTube & 2005 & $\begin{array}{c}\text { Chad Hurley, Steven Chen and } \\
\text { Jawed Karim }\end{array}$ & 1000+ Million & Video hosting/sharing site \\
\hline StumbleUpon & 2002 & Garrett Camp and Geoff Smith & 40 Million & $\begin{array}{l}\text { Discovery engine, social } \\
\text { networking }\end{array}$ \\
\hline MySpace & 2003 & Chris DeWolfe and Tom Anderson & $\begin{array}{l}36 \text { Million } \\
\text { (Oct. 2013) }\end{array}$ & General social networking site \\
\hline LinkdIn & 2002 & Reid Hoffman & 259 Million & $\begin{array}{c}\text { Business and } \\
\text { Professional Networking }\end{array}$ \\
\hline Google+ & 2011 & Larry Page and Sergey Brin & $\begin{array}{l}300 \text { Million } \\
\text { (Jan. 2014) }\end{array}$ & General social networking site \\
\hline Pinterest & 2010 & $\begin{array}{c}\text { Ben Silbermann, Paul Sciarra and } \\
\text { Evan Sharp }\end{array}$ & 20 Million & Visual discovery tool \\
\hline Tumblr & 2007 & David Karp & $\begin{array}{l}230 \text { Million } \\
\text { (Jan. 2014) }\end{array}$ & $\begin{array}{l}\text { Social networking site, } \\
\text { Micro-blogging }\end{array}$ \\
\hline reddit & 2005 & Steve Guffman and Alexis Ohanian & $\begin{array}{l}\text { 114.9 Million } \\
\text { (April 2014) }\end{array}$ & Social news, social networking site \\
\hline Orkut & 2004 & Orkut Büyükkökten & Dissolved & General social networking site \\
\hline
\end{tabular}

Source: www.wearesocial.sg, January 2014.

granted the citizens of the Arab world access to new sources of information [18]. Earlier used merely as a tool for social networking and entertainment, social media now infiltrates almost every aspect of the daily lives of millions of Arabs, affecting the way they interact socially, do business, engage with government, and take part in civil society movements [19].

The influence of social media has been felt in the recent political uprisings in the Arab world. In both Tunisia and Egypt, the tools of social media played a crucial role in mobilizing [8] [16]. Whether it is Facebook, Twitter, YouTube, Google or Blogs, they all have found themselves central to the uprisings in an unprecedented way. Researchers have claimed that social media has promoted a more open ideology [20], a strong social and political bond [21] and serves as a means of communication and exchange of ideas [22] and as a platform facilitating political dialogue [23] across the Arab world. However, a number of critics of social media across the world argue that the role of social media has been exaggerated [24]. Still, many believe that social media played an integral part in the political uprisings of the Arab region [25].

Although Arabs have rapidly adapted new technologies to their needs, online privacy concerns are highly sensitive issues in the Middle East, and in some cases protective actions have been taken [26]. However, studies show that increasing censorship and government regulations have actually fuelled the growth of social media in this region [27] [28].

\section{Research Problem}

We have entered into an era where library professionals need to keep track of every new innovation. Social media, due to their huge capabilities to support connection and communication, have received much attention by researchers, educators, students and even ordinary people. Library professionals need to know the best SNSs used mostly in their respective countries and elsewhere. This study aims to solve this problem by unfurling the highly used SNSs across the Arab Gulf States.

\section{Scope and Objective of the Study}

The study is intended to evaluate the use and growth of social networking sites among Arab Gulf States, com- 
prising Iraq, Kuwait, United Arab Emirates, Oman, Qatar, Bahrain and Saudi Arabia. The data related to 2011, 2012 and 2013 are taken for analysis.

\section{Methodology}

In order to achieve the above stated objective, database of StatCounter (http://gs.statcounter.com) was selected for tracing the use and growth of SNSs in the Arab Gulf States. StatCounter is a web traffic analysis tool, used primarily for computing usage share of websites. The data as such gathered were thoroughly analyzed and compressed for the necessary information.

\section{Data Analysis and Discussion}

\subsection{Kingdom of Saudi Arabia}

Saudi Arabia, the $2^{\text {nd }}$ most populated country in the Arab Gulf States, rank $6^{\text {th }}$ as far as the number of internet users is concerned (Table 2). The users were mainly using Facebook in 2011 (90.42\%) and 2012 (61.17\%) but in 2013 trend changes and Twitter dominated the market (60.4\%). Twitter was having a meagre share in 2011 (2.85\%) and 2012 (20.46\%) but it gained a huge market in 2013 with a 39.94\% jump during 2012-2013. Facebook has lost its market share considerably from $61.17 \%$ in 2012 to $35.68 \%$ in 2013. YouTube gained some market in 2012 (16.7\%) in comparison with its little market share in 2011 (4.66\%) but declined in 2013 (2.74\%), yet retained $3^{\text {rd }}$ place. StumbleUpon and NowPublic also have lost their market share since 2011, while the former is still used by a few people; the latter is out of the market in 2013. However, some other SNSs like Tumblr and Google+ have shown their presence in 2013 which were not in the market in 2011. Figure 1 offers vivid details.

\subsection{State of Qatar}

Qatar being $6^{\text {th }}$ highly populated country in the Arab Gulf region, rank $1^{\text {st }}$ in the number of internet users. Facebook has almost dominated the whole market by maintaining $1^{\text {st }}$ position for all the three years. Although it observed a little decline in its market share in 2012 (76.48\%) as compared to $88.23 \%$ in 2011 but again increased to $83.65 \%$ in 2013. However, it has lost more than $4 \%$ market share since 2011 due to Twitter. The market share of Twitter increased consistently from a meagre $2.7 \%$ in 2011 to $4.79 \%$ in 2012 and $10.67 \%$ in 2013 . YouTube was the $2^{\text {nd }}$ most used SNS in two consecutive year with $4.08 \%$ (2011) and $14.76 \%$ (2012) market share, but it has lost its market in 2013 (2.35\%) and placed in $3^{\text {rd }}$ position after Twitter. StumbleUpon and reddit have lost their market share since 2011 (Figure 2).

\subsection{Sultanate of Oman}

Oman is the $4^{\text {th }}$ most populated country in the Arab Gulf region and rank $5^{\text {th }}$ as far as the number of internet users is concerned. Facebook has maintained the top spot for all the three years, but its market share is constantly declining from $89.89 \%$ in 2011 to $61.38 \%$ in 2012 and $52.79 \%$ in 2013 . This is due to increase in the market share of Twitter from the mere $2.29 \%$ in 2011 to $14.2 \%$ in 2012 and 39.39\% in 2013. Facebook has lost almost $37 \%$ market share to Twitter since 2011. YouTube gained some market in 2012 (20.46\%) as compared to 4.08\% market share in 2011 but declined drastically in 2013 (3.66\%) and moved to $3^{\text {rd }}$ place after Twitter. While StumbleUpon and LinkdIn have lost their market share since 2011, some other SNSs like Pinterest, Tumblr and Google+ have shown their presence in the market in 2013. Figure 3 provides a lucid view of the whole discussion.

\subsection{State of Kuwait}

Kuwait being $5^{\text {th }}$ highly populated country in the Arab Gulf States, rank $3^{\text {rd }}$ in the number of internet users. Like Saudi Arabia, the users in Kuwait were mainly using Facebook until 2011 (84.54\%) but trends have changed ever since and market share of Twitter skyrocketed from negligible 6.56\% in 2011 to $34.95 \%$ in 2012 and 64.18\% in 2013. Since 2011, while Facebook has lost about 52\% of its market share, Twitter has gained over $57 \%$ user population and achieved $1^{\text {st }}$ position replacing Facebook. YouTube gained some popularity in 2012 (10.91\%) in comparison with its small market share in 2011 (4.59\%) but again decreased to $1.6 \%$ in 2013, yet 
Table 2. Internet usage in the Arab Gulf States.

\begin{tabular}{ccccc}
\hline Arab Gulf States & $\begin{array}{c}\text { Population } \\
\text { (2012 Est.) }\end{array}$ & $\begin{array}{c}\text { Internet Usage } \\
\text { 30-June-2012 }\end{array}$ & \% of Internet users & Rank in Arab Gulf region \\
\hline Qatar & $1,951,591$ & $1,682,271$ & $86.2 \%$ & 2 \\
Bahrain & $1,248,348$ & 961,228 & $77.0 \%$ & $74.2 \%$ \\
Kuwait & $2,646,314$ & $1,963,565$ & $70.9 \%$ & 4 \\
UAE & $8,264,070$ & $5,859,118$ & $68.8 \%$ & 4 \\
Oman & $3,090,150$ & $2,101,302$ & $49.0 \%$ & $7.1 \%$ \\
Saudi Arabia & $26,534,504$ & $13,000,000$ & 7 \\
\hline
\end{tabular}

Source: Internet World Stats.

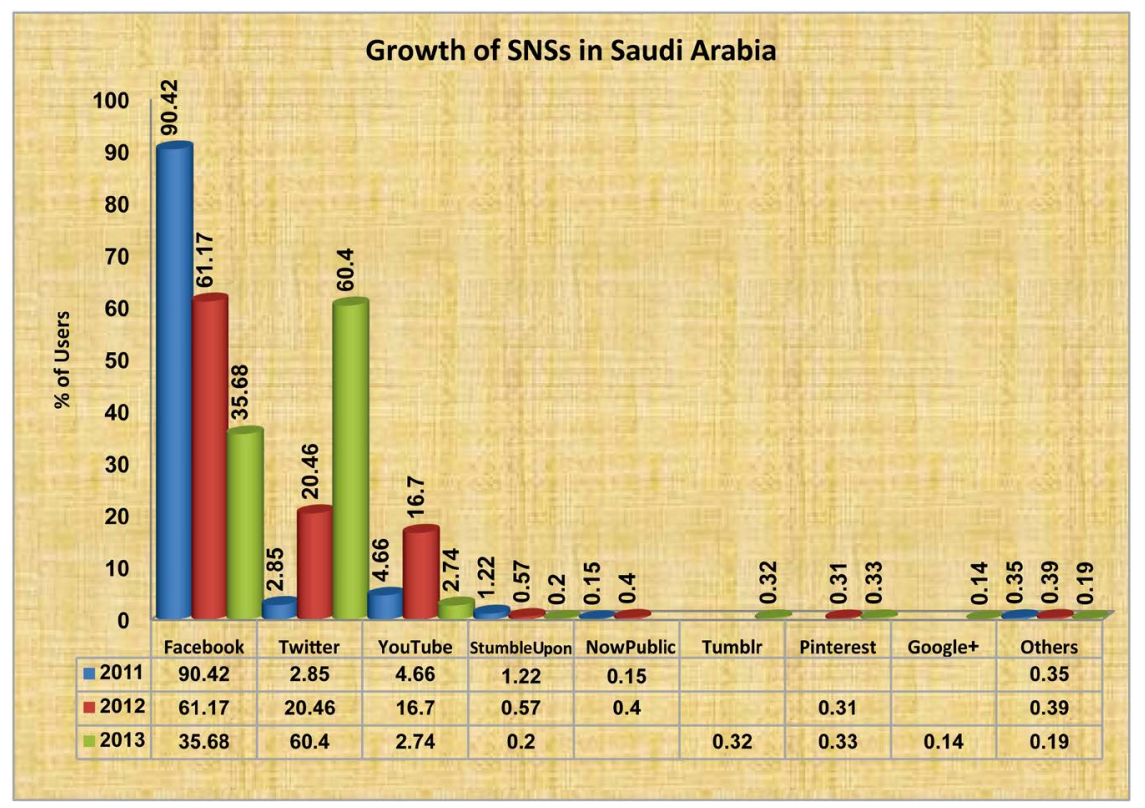

Figure 1. Annual growth of SNSs in Saudi Arabia.

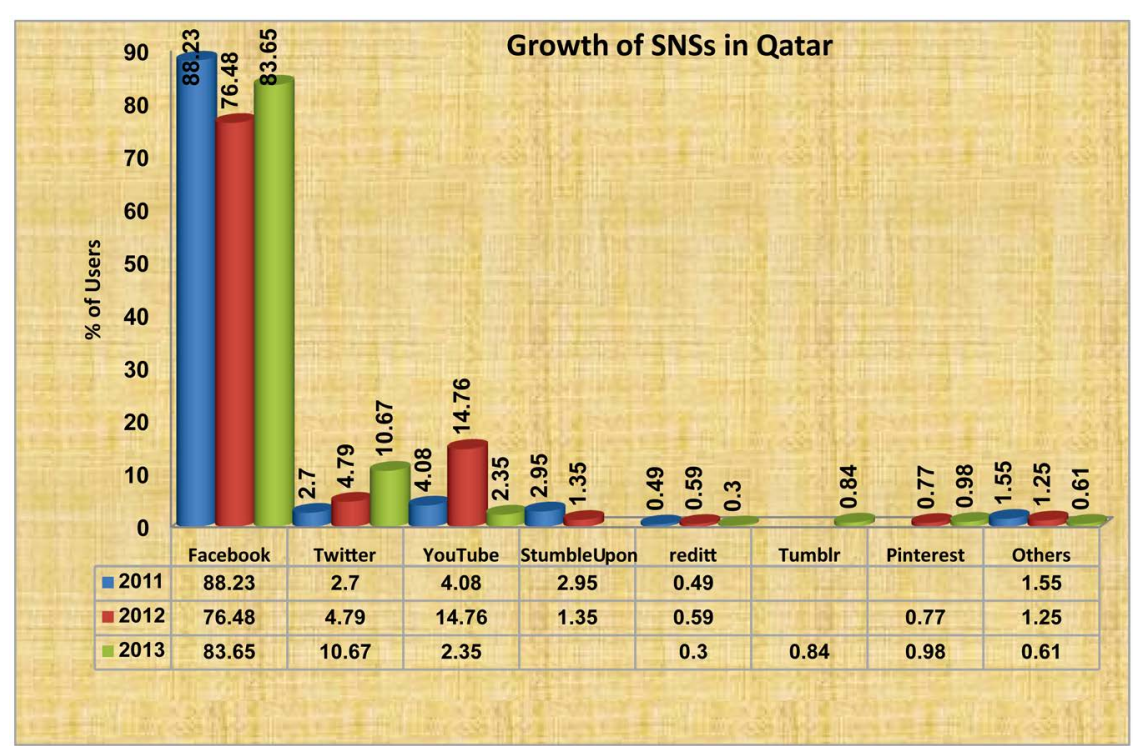

Figure 2. Annual growth of SNSs in Qatar. 


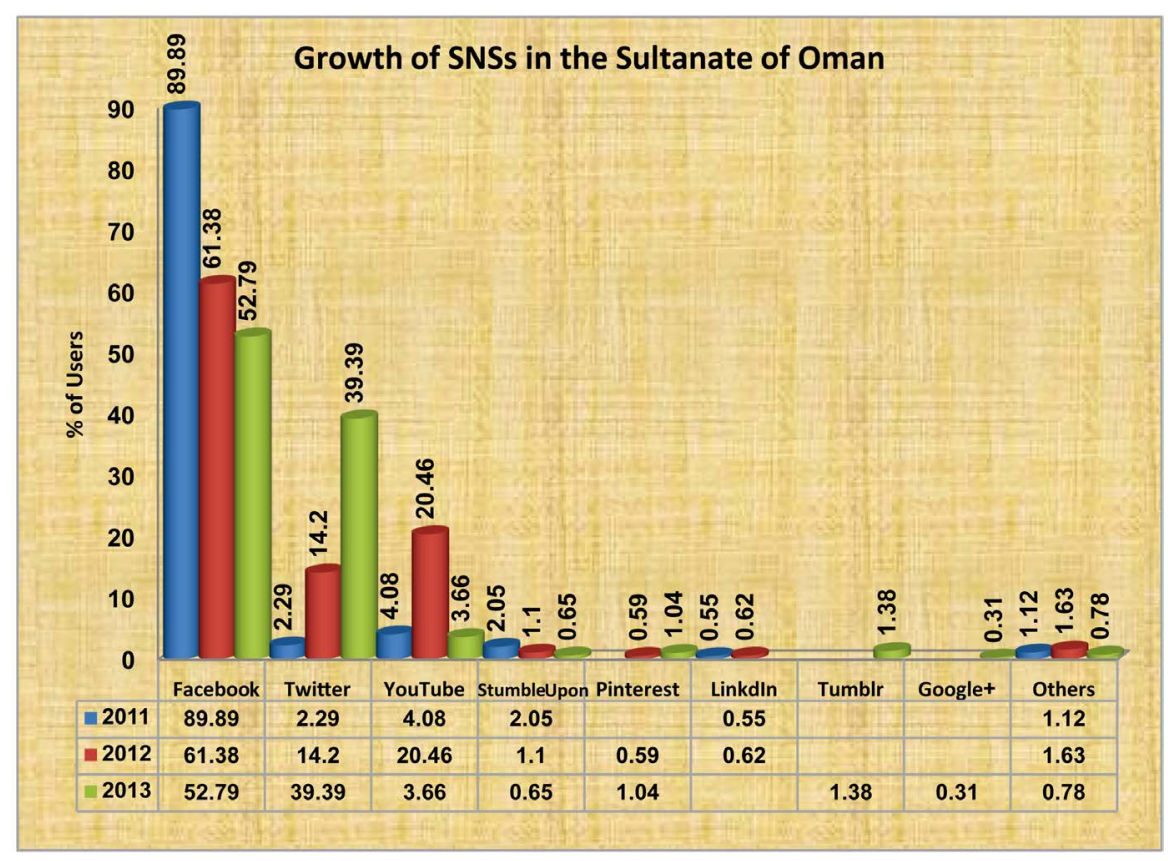

Figure 3. Annual growth of SNSs in Oman.

retained its $3^{\text {rd }}$ position in the market. StumbleUpon has maintained its $4^{\text {th }}$ spot from 2011 to 2013 but gradually lost its user base. The other SNSs like reddit, Pinterest, LinkdIn and Tumblr have very few users in Kuwait (Figure 4).

\subsection{The United Arab Emirates}

United Arab Emirates is the $3^{\text {rd }}$ most populated country in the Arab Gulf region and rank $4^{\text {th }}$ as far as the number of internet users is concerned. Facebook has almost dominated the whole market by maintaining $1^{\text {st }}$ position consistently for the last three years. However, the market share of Facebook witnessed a slight decline in 2012 (76.84\%) as compared to 88\% in 2011 but again increased to $78.52 \%$ in 2013. Similar to other countries of the Gulf region, the UAE has also shown a significant increase in the user population of Twitter from a negligible 2.72\% in 2011 to $6.65 \%$ in 2012 and 13.6\% in 2013. The data analysis thus revealed that Facebook has lost about $10 \%$ of its market share to Twitter since 2011. On the other hand, YouTube, which was the $2^{\text {nd }}$ most used SNS in the UAE in the year $2011(4.02 \%)$ and 2012 (11.66\%), dipped to $3^{\text {rd }}$ position in 2013 with its all time low market share (2.76\%). StumbleUpon has, however, maintained its $4^{\text {th }}$ spot, but lost its market share gradually from 2011 to 2013. Furthermore, it is evident from the data analysis shown in Figure 5 that other Social Networking Sites like, Pinterest, Tumblr and LinkdIn have little or no market share in the UAE.

\subsection{Kingdom of Bahrain}

Bahrain, being the $6^{\text {th }}$ highly populated country of the Arab Gulf States, rank $2^{\text {nd }}$ in the number of internet users. The data analysis revealed that Facebook has maintained the top spot for all the three years, but shown a considerable decrease in its market share from a whopping $82.94 \%$ in 2011 to $58.57 \%$ in 2012 and $54.3 \%$ in 2013. Twitter, the $2^{\text {nd }}$ most used SNS in Bahrain with a 10.25\% market share in 2011, has witnessed a considerable market growth similar to other Arab countries and reached to $26.26 \%$ in 2012 and 37.81\% in 2013. YouTube gained some market in 2012 (9.67\%) from a poor $2.53 \%$ in 2011 and moved to $3^{\text {rd }}$ position but declined again in 2013 (2.44\%). StumbleUpon dipped from $3^{\text {rd }}$ position in 2011 to $4^{\text {th }}$ position in 2012 and 2013. Social Networking Sites such as Pinterest, reddit and Tumblr have a negligible market share in Bahrain as depicted clearly in Figure 6.

\subsection{Republic of Iraq}

Iraq, the most populated country in the Arab Gulf States, rank $7^{\text {th }}$ as far as the number of internet users is 
concerned. The percentage of internet users (7.1\%) as compared to other countries in the region is very poor. In Iraq, Facebook has almost dominated the whole market by maintaining $1^{\text {st }}$ spot consistently for the last three years. However, the market share of Facebook has witnessed a slight decrease in 2012 (86.21\%) as compared to 95.26\% in 2011 but again increase to $92.39 \%$ in 2013. YouTube has maintained its $2^{\text {nd }}$ position from 2011 to 2013. Although, it has increased considerably in 2012 (11.8\%), but lost its market share again in 2013 (4.99\%). Twitter and StumbleUpon have a very little market share in Iraq as shown in Figure 7.

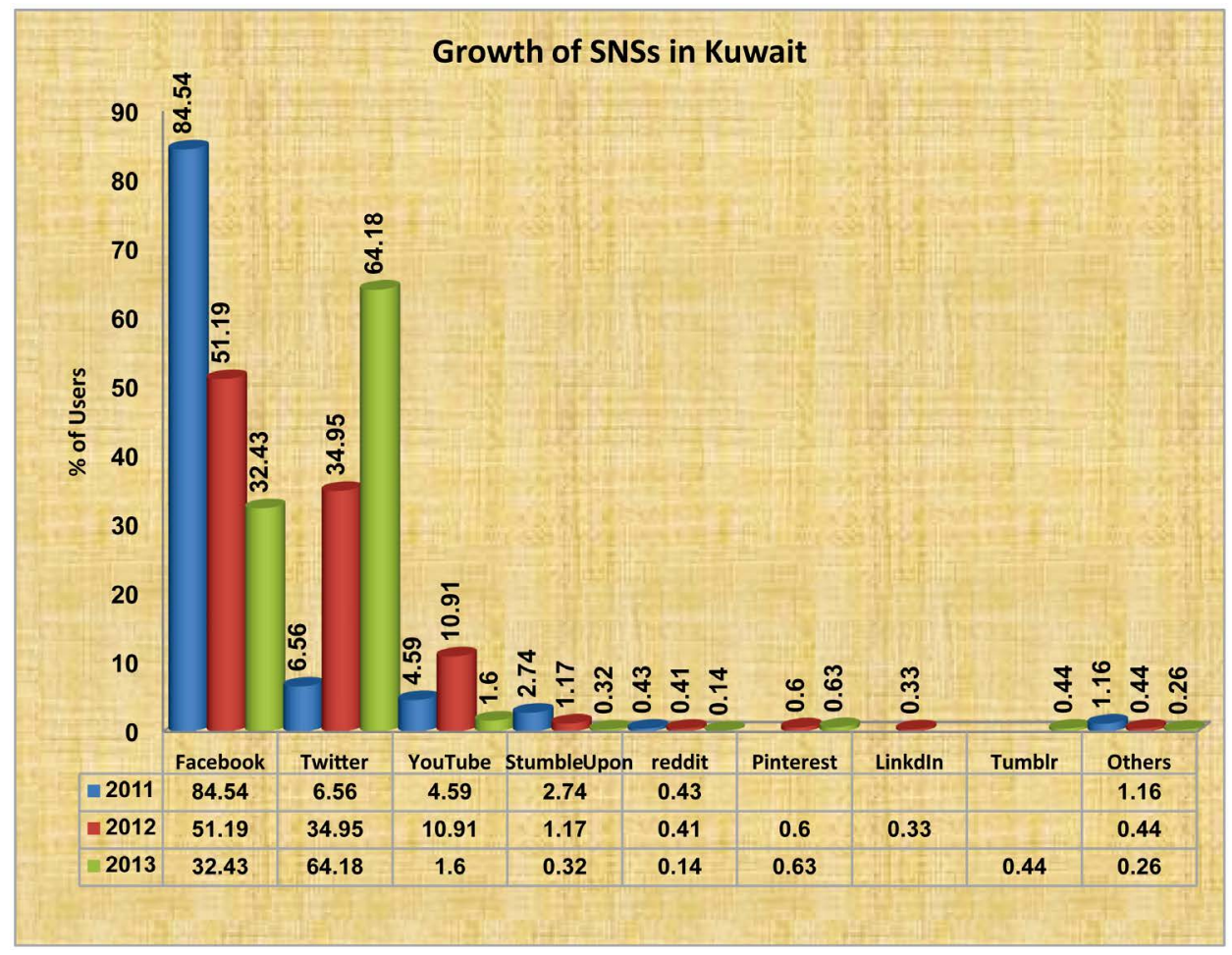

Figure 4. Annual growth of SNSs in Kuwait.

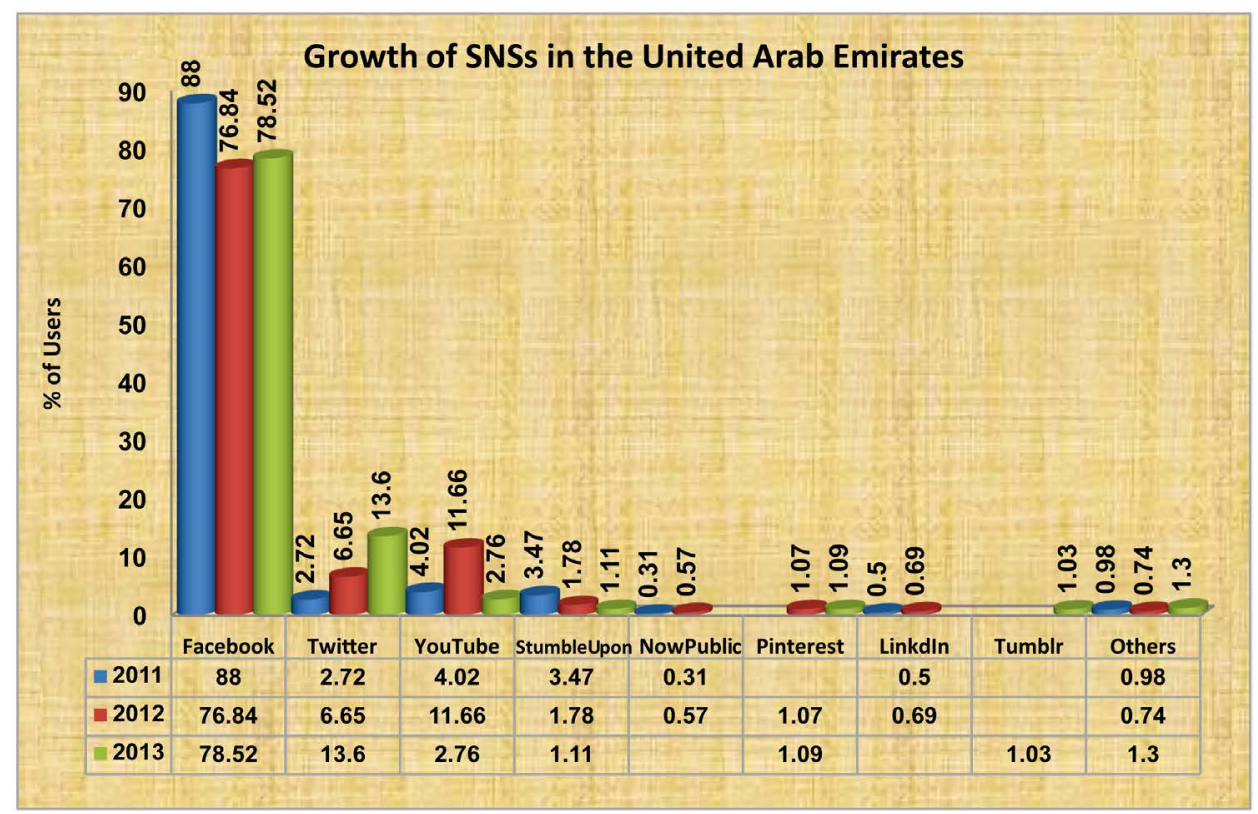

Figure 5. Annual growth of SNSs in the UAE. 


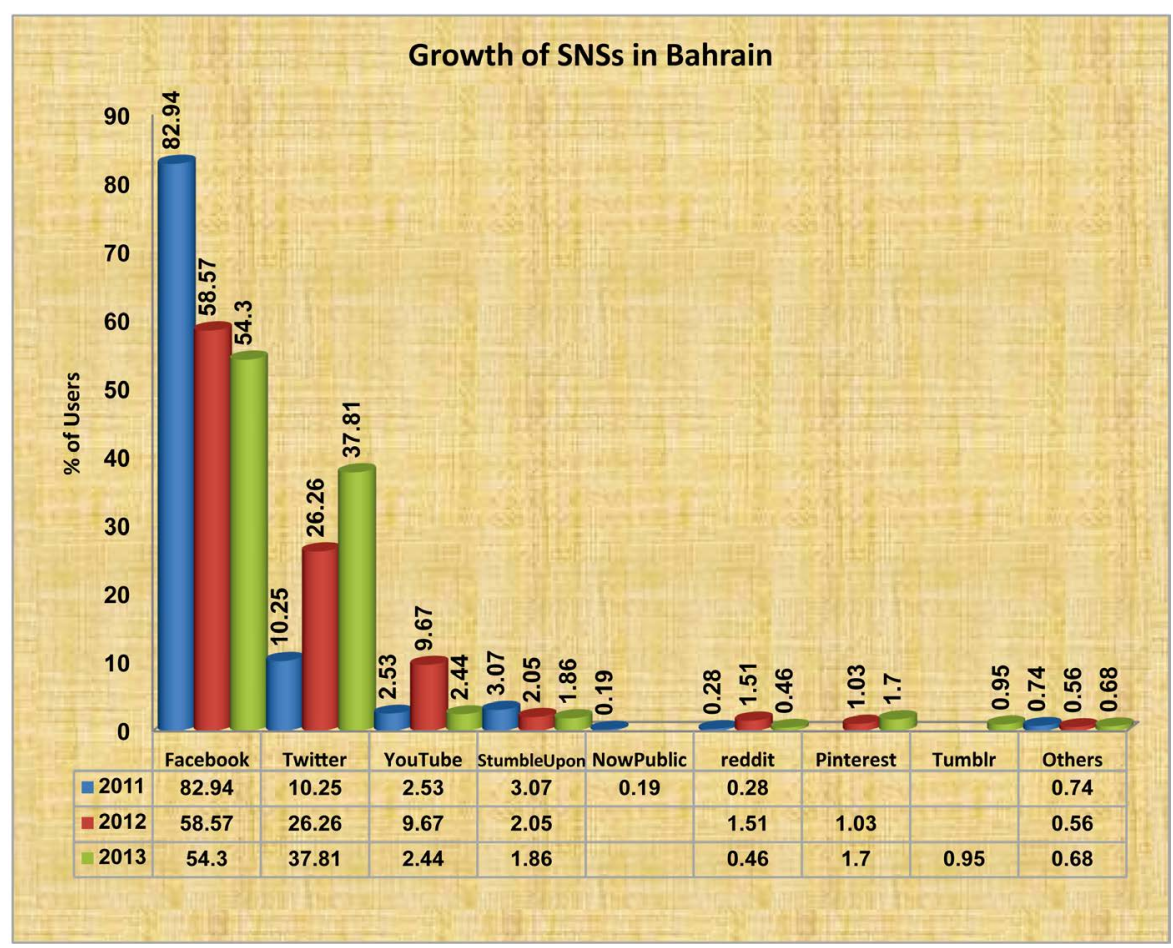

Figure 6. Annual growth of SNSs in Bahrain.

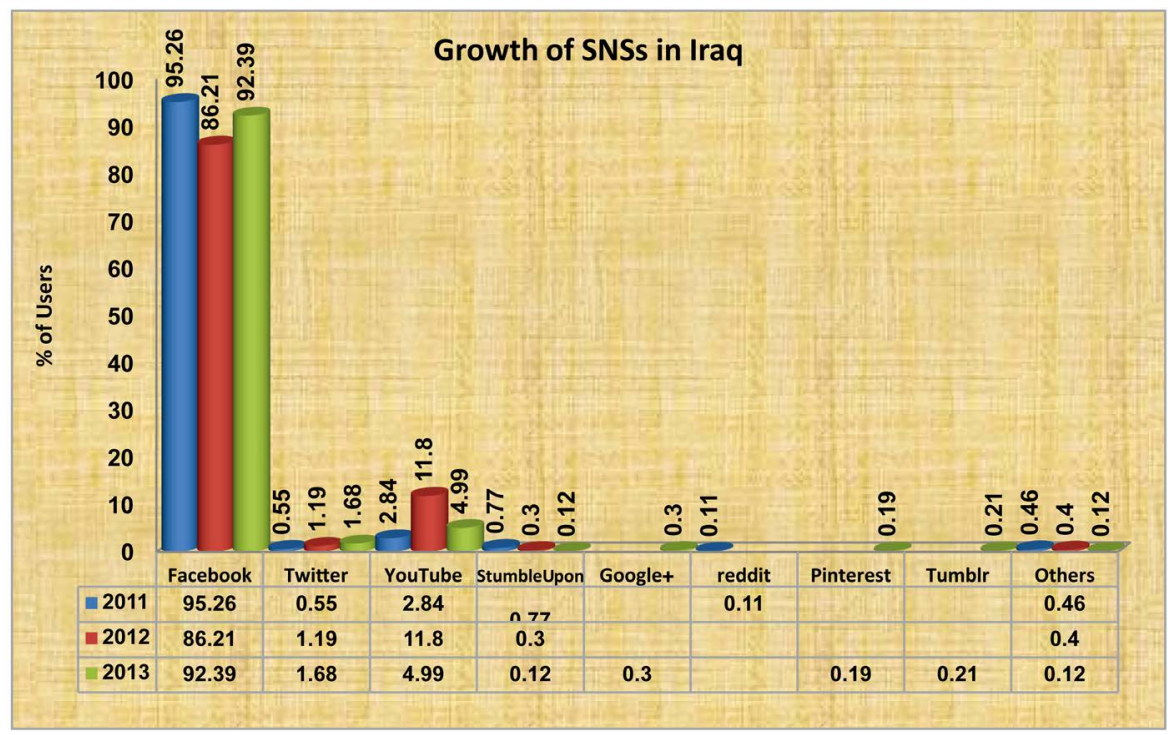

Figure 7. Annual growth of SNSs in Iraq.

\section{Conclusions}

The impact of SNSs is tremendous on every aspect of life and people irrespective of region, gender and age are using it to get connected with friends, acquaintances, ideological clubs, scientific forums, etc. It can also unite people with common interests and/or beliefs through groups and other pages, and has been known to reunite lost family members and friends. The three most used SNSs in the Arab Gulf region are: Facebook, Twitter and YouTube. It has been observed that Facebook is the leading social networking site used in all the Arab Gulf countries until now, but Twitter is fast gaining market in this region. Twitter, as evident from the data analysis, is becoming popular among users and giving a tough competition to Facebook in almost all countries of the 
region except Iraq. In 2013, it has moved to $1^{\text {st }}$ position in Saudi Arabia and Kuwait, replacing Facebook. However, in some countries like the UAE and Qatar, Facebook is still going strong. In Iraq, Facebook alone has dominated the market so far. However, the data analysis revealed a very low percentage of internet users in Iraq as compared to other Arab Gulf States. It is interesting to note that in 2012, YouTube had witnessed an increase in its market share in all the countries of the Arab Gulf region but decreased heavily in 2013.

The study concludes that the future of social networking sites in the Arab Gulf countries looks brighter as the new social networking sites are constantly popping up while the existing ones changing. The user population for these sites are also constantly increasing encompassing people of all ages and social backgrounds.

\section{Limitation of the Study}

StatCounter tracking code is installed on more than 3 million sites globally. Every month, more than 15 billion hits are recorded to these sites. As such the data collected do not claim to be the sole representation of the whole internet user community.

\section{References}

[1] Internet World Stats: Usage and Population Statistics (2014). http://www.internetworldstats.com/emarketing.htm

[2] Ahmed, A. and Al Reyaee, S. (2014) Coping the Budget Pressure: Possibility of Adopting Open Source Solutions in Saudi Libraries: A Review. e-Library Science Research Journal, 2, 1-15. http://www.lsrj.in/UploadedArticles/175.pdf

[3] Agarwal, N., Liu, H. and Zhang, J. (2009) A Study of Friendship Networks and Blogosphere. In: Kock, Ed., E-Collaboration: Concepts, Methodologies, Tools and Applications, IGI Global, chap. 55, 661-684.

[4] Boyd, D. and Ellison, N. (2007) Social Network Sites: Definition, History, and Scholarship. Journal of ComputerMediated Communications, 13, 210-230. http://www.danah.org/papers/JCMCIntro.pdf http://dx.doi.org/10.1111/j.1083-6101.2007.00393.x

[5] White, C., Plotnick, L., Kushma, J., Hiltz, S.R. and Turoff, M. (2009) An Online Social Network for Emergency Management. In: Landgren, J., Nulden, U. and Van de Walle, B., Eds., Proceedings of the 6th International ISCRAM Conference, Gothenburg, May 2009, 369.

[6] Mansour, E. (2012) The Role of Social Networking Sites (SNSs) in the January 25th Revolution in Egypt. Library Review, 61, 128-159. http://dx.doi.org/10.1108/00242531211220753

[7] Arora, A. (2008) The Story of Social Networking upon the Internet: The Real Game. Bright Hub, 15 December 2008. http://www.brighthub.com/computing/windows-platform/articles/19325.aspx

[8] Al-Badi, A.H. (2014) The Adoption of Social Media in Government Agencies: Gulf Cooperation Council Case Study. Journal of Technology Research, 5, 1-26. http://www.aabri.com/manuscripts/131643.pdf

[9] Bargh, J.A. and McKenna, K.Y.A. (2004) The Internet and Social Life. Annual Review of Psychology, 55, 573-590. http://www.uam.es/personal_pdi/psicologia/pei/download/bargh2004.pdf http://dx.doi.org/10.1146/annurev.psych.55.090902.141922

[10] Liu, H. (2008) Social Network Profiles as Taste Performances. Journal of Computer-Mediated Communication, 13, 252-275. http://dx.doi.org/10.1111/j.1083-6101.2007.00395.X

[11] Choi, S.M., Kim, Y., Sung, Y. and Sohn, D. (2011) Bridging or Bonding? A Cross-Cultural Study of Social Relationships in Social Networking Sites. Information, Communication \& Society, 14, 107-129. http://dx.doi.org/10.1080/13691181003792624

[12] Luo, J.S. (2007) Social Networking: Now Professionally Ready. Primary Psychiatry, 14, 21-24. http://primarypsychiatry.com/social-networking-now-professionally-ready/

[13] Hempel, J. and Lehman, P. (2005) The MySpace Generation. Business Week, 3963, 88-93.

[14] Dwyer, C., Hiltz, S.R. and Passerini, K. (2007) Trust and Privacy Concern within Social Networking Sites: A Comparison of Facebook and MySpace. Proceedings of AMCIS 2007, Keystone.

http://csis.pace.edu/ dwyer/research/DwyerAMCIS2007.pdf

[15] Feenberg, A. (2002) Transforming Technology: A Critical Theory Revisited. Oxford Press, Oxford.

[16] Al Jenaibi, B.N.A. (2011) Use of Social Media in the United Arab Emirates: An Initial Study. Global Media Journal, 1, 3-27.

[17] Arab Media Forum (2014) Arab Social Media Outlook 2014. http://www.mbrsg.ae/getattachment/713949a1-6f4c-4c06-b1a3-bf1df01efc25/Arab-Social-Media-Outlook-2014.aspx 
[18] Ghannam, J. (2011) Social Media in the Arab World: Leading up to the Uprisings of 2011. Center for International Media Assistance, Washington, DC.

[19] Mourtada, R. and Salem, F. (2012) Social Media in the Arab World: The Impact on Youth, Women and Social Change. Panorama, 269-274.

http://www.iemed.org/observatori-en/arees-danalisi/arxius-adjunts/anuari/med.2012/mourtada\%20salem_en.pdf

[20] Gitelman, L. and Pingree, G.B. (2003) New Media, 1740-1915 (Media in Transition). New World, Montréal.

[21] Mohamed-Nour, S.S.O. (2005) Technological Change and Skill Development in the Arab Gulf Countries. Universitaire Pers Maastricht, Maastricht.

[22] Luna, E. (2011) Egypt, Libya, Tunisia: Twitter Revolutions? http://tuftsdaily.com/multimedia/2011/03/11/egypt-libya-tunisia-twitter-revolutions/

[23] Ghazi, J. (2011) Social Media Made Tunisian Uprising Possible. New America Media. http://newamericamedia.org/2011/01/social-media-made-tunisian-uprising-possible.php

[24] Murphy, E.C. and Zweiri, M. (2011) The New Arab Media: Technology, Image and Perception. Ithaca Press, Ithaca, NY.

[25] Wright, M. (2011) Social Media Revolution? http://www.wrightresult.com/2011/02/social-media-revolution-live/

[26] Borenstein, J. (2008) Privacy: A Non-Existence Entity. IEEE Technology and Society Magazine, 27, 20-26. http://dx.doi.org/10.1109/MTS.2008.930565

[27] MediaME.com (2010) UAE Internet Users Concerned about Internet Privacy. http://www.albawaba.com/business/uae-internet-users-concerned-about-internet-privacy

[28] Azam, M. (2011) Revolution + Facebook Doesn’t Equal Social Media Revolution. In These Times, 1 March 2011. 